riamente rigoroso e crítico, nāo estâ acompanhando o ritmo das mudanças no universo das relaçōes políticas e sociais. Este, sem dúvida, é um dos momentos mais difíceis da atribulada convivência no exercício científico com a urgência da prática política" (pp. 10-11). Os textos são, pela ordem de apresentação, os seguintes: "Filosofia e Política" - Nilo Odália; "Há uma Crise nas Ciências Sociais? "- José Carlos Bruni; "A Tirania do Olhar" - Roberto Romano; "Crise do Marxismo e Política" - Marco Aurélio Nogueira; "'A Morte' do Marxismo e a Democracia" - Iná Camargo Costa: "Democracia e Revoluçăo" - Cristina Diniz Mendonça; "Rumos do Estado na Sociedade Contemporânea" - Oliveiros S. Ferreira "Voto e Mercado na Sociedade Competitiva" - Reginaldo de Moraes; "Transiçăo e Cidadania no Brasil Contemporàneo - Gildo Marçal Brandáo; "As Determinaçōes da Longa Duraçẫo e sua Conversăo: 0 impasse" - Fausto Castilho; e "A Astúcia do Príncipe e a Invençăo da República" ${ }^{\text {- Luiz }}$ Werneck Vianna.

$O$ Pensamento em Crise $e$ as Artimanhas do Poder, na maioria de seus textos, constitui-se em instigante reflexão acerca das possibilidades e dos limites das ciências (humanas) no sentido de fornecer alguns parâmetros para a compreensăo de várias dimensóes da sociedade brasileira atual - o que, no meu entender, transforma-o em leitura fundarnental para os cidadãos que se interessam pela "realidade" que os cercam.

\section{o CAPITALISMO, SUA EVOLUÇÃo, SUA LOGICA E SUA DINÂMICA}

Paul Singer.

Săo Paulo, Editora Modema, 1987.

Por Sollval Silva Menezes

Doutorando em Economia no IPENSP, mestrando em Finanças na EAESP/FGV.

Neste interessante livro de pouco mais de oitenta páginas, o reconhecido economista e Secretário Municipal de Planejamento de São Paulo, Paul Singer, consegue traduzir em poucas e boas palavras a dinâmica do modo de produção capitalista, tornando acessível ao leigo um pouco da história e da teoria econômica.

E uma obra que reflete a preocupação do au* tor em tornar a ciência um instrumento de compreensão da realidade, permitindo ao homem comum "driblar" o economês e entender o que quis dizer Marx, Keynes ou os neoclássicos sem necessariamente recorrer a teoremas e hipóteses originais, mas usando palavras comuns do entendimento de todos.

Refutando as definiçōes, por exigirem prévio conhecimento do leitor, Singer apresenta o Capitalismo a partir de sua tendência de transformar tudo que é desejável em objeto do comércio, destacando sua evolução histórica em paralelo ao nascimento das teorias que tentam explicar o funcionamento do sistema econômico. Mostra, por exemplo, que o Capitalismo, não obstante suas graves deficiências do ponto de vista da produçăo e distribuição, trouxe avanços consideráveis para a humanidade, contabilizando ganhos científicos e evoluçốes sociais que beneficiaram também as camadas mais baixas das pirâmides econômicas (os trabalhadores). Esses ganhos, entretanto, têm sido historicamente muito maiores para as classes dominantes que para os trabalhadores, residindo aí, na opiniăo do autor, uma das faIhas que leva o capitalismo a ser tão criticado.

Muito interessante é a demonstração da lógica do capitalismo a partir da produção simples de mercadorias e do conflito de classes, desembarcando na ocorrência das crises de realização e dos ciclos econômicos. Neste ponto, säo inevitáveis as referências à grande crise dos anos 1930, com o autor destacando o nascimento, do ponto de vista teórico, da nova ortodoxia econômica fundamentada em Myrdal, Kaleckí e Keynes.

Outra parte importante do livro é a que especula sobre o fim do Capitalismo, onde Singer, não obstante sua clara filiação marxista, demonstra ceticismo quanto a um futuro comunista da civilização nos termos que Marx previu. Ao invés disso, argumenta que uma das possiveis trajetórias do atual modo de produção ê "a sua transformação, gradual e indolor, em uma espécie de economia internacional semiregulada por órgãos intergovernamentais, em conjunto e/ou conflito com os governos das grandes potencias". Outro caminho possível seria o renascimento do movimento anticapitalista que, no entanto, nāo destruiria o modo de produção, mas buscaria um caminho alternativo que eliminaria a atual autocracia empresarial, colocando os trabalhadores em seu lugar.

Trata-se, enfim, de uma obra impar que merece ser lida por todos aqueles que desejam uma visão coloquial da Economia sem cair no banal. Seu autor revela, além de uma grande capacidade de simplificar a Economia, uma grande crença na democracia enquanto corolário de uma sociedade mais igualitaria e onde as estruturas hierarquizantes são meras fábulas. 